\title{
Działalność redakcyjno-wydawnicza ks. Henryka Antoniego Szumana na rzecz najmłodszych odbiorców. Na przykładzie „Naszego Przewodnika” (1913-1919)
}

\section{Wprowadzenie}

„Nasz Przewodnik" był ilustrowanym (obrazkowym) miesięcznikiem adresowanym do dzieci szkolnych należących do kółek abstynenckich, zwanych na Pomorzu, w Wielkopolsce i w Królestwie Polskim Bractwami Dzieciątka Jezus, a w Galicji Związkami Anioła Stróża' ${ }^{1}$. Nabywali, prenumerowali i czytali go również promotorzy (opiekunowie) tych dziecięcych bractw wstrzemięźliwości, a więc księża proboszczowie, prefekci, katecheci szkolni oraz bardziej zaangażowani wychowawczo rodzice i nauczyciele. Periodyk ukazywał się od stycznia 1913 do grudnia 1920 r. Jego inicjatorem, wydawcą i redaktorem był do końca 1919 r. ks. Henryk Szuman.

\section{Ksiądz Henryk A. Szuman - życie i działalność}

Henryk Antoni Szuman urodził się 13 czerwca 1882 r. w Toruniu w rodzinie inteligenckiej. Jego ojciec Leon był cenionym w mieście lekarzem - chirurgiem, zwanym „lekarzem ubogich”, a zarazem znanym działaczem społecznym i patriotą.

* Dr, Uniwersytet Jana Kochanowskiego w Kielcach, Wydział Humanistyczny, Instytut Bibliotekoznawstwa i Dziennikarstwa, Zakład Historii Prasy i Książki, 25-406 Kielce, ul. Świętokrzyska 21D.

${ }^{1} \mathrm{Na}$ temat Bractw Dzieciątka Jezus i Związków Anioła Stróża szerzej: I. Krasińska, „Łatwiej zapobiec chorobie, niż ją wyleczyć". Bractwa Dzieciątka Jezus i Związki Anioła Stróża - dziecięce kółka abstynenckie na ziemiach polskich w latach 1912-1914, [w:] Virginibus puerisque, t. 2: Z zagadnień wychowania i opieki nad dzieckiem w XVIII-XX wieku, red. E. Kula, M. Pękowska, Kielce 2012, s. $145-151$. 
Natomiast matka Eugenia z domu Gumpert zajmowała się domem i wychowaniem ośmiorga dzieci, a ponadto pomagała mężowi w opiece nad pacjentami oraz działała społecznie w toruńskim Towarzystwie Pomocy Naukowej dla Dziewcząt. To właśnie matka dostrzegła u młodego Henryka tendencje do poświęcenia się w przyszłości służbie Bogu i ludziom. Henryk Szuman nauki pobierał najpierw w jednym z najstarszych na Pomorzu Gdańskim niemieckim gimnazjum ewangelickim, gdzie uczyła się duża grupa młodzieży katolickiej. W czasach gimnazjalnych należał do tajnej patriotycznej organizacji młodzieży polskiej, tzw. „Filomatów”, której był nawet (ok. 1900 r.) przewodniczącym. W ramach tej organizacji uczył kolegów języka polskiego oraz literatury ojczystej. Organizacja „Filomatów” została jednak przez władze pruskie wykryta, a należąca do niej młodzież szkolna nie uniknęła represji i prześladowań. Wśród oskarżonych i sądzonych znalazł się również Henryk Szuman, który choć uniewinniony, lecz zmuszony został do przerwania nauki. Maturę zdał dopiero w roku $1904^{2}$.

Po ukończeniu gimnazjum Henryk Szuman wstąpił do Seminarium Duchownego w Pelplinie. Podczas studiów w seminarium dał się poznać jako propagator wstrzemięźliwości, zachęcając m.in. kleryków do abstynencji od napojów alkoholowych. Już wówczas zetknął się z działalnością istniejącego od 13 września 1902 r., początkowo na terenie archidiecezji gnieźnieńskiej i poznańskiej, Związku Księży Abstynentów, którego inicjatorem był diakon Seminarium Duchownego w Poznaniu Franciszek Olejniczak $^{3}$, a prezesem ks. Kazimierz Niesiołowski ${ }^{4}$ - proboszcz z Pleszewa ${ }^{5}$. Święcenia kapłańskie Henryk Antoni Szuman przyjął 23 lutego 1908 r. Po święceniach pracował jako wikary w Brodnicy, Lubichowie, Dobrczu ${ }^{6}$, a ponadto w latach 1911-1912 studiował na Uniwersytecie Jagiellońskim, gdzie współpraco-

2 H. Mross, Szuman Henryk Antoni, [w:] Słownik polskich teologów katolickich 1918-1981, t. 7: R-Z, red. L. Grzebień, Warszawa 1983, s. 246; A. Wałęga, Ksiądz Henryk Antoni Szuman (18821939) jako reprezentant pedagogiki opiekuńczo-wychowawczej, „Pedagogia Christiana” 2006, t. 2, s. 165-168; K. Dąbrowski, Ksiądz prałat Henryk Antoni Szuman. Życie i działalność, „Studia Pelplińskie" 1976, s. 43-44.

${ }^{3}$ Franciszek Olejniczak (1877-1965), kapłan katolicki, działacz społeczny i oświatowy. Już podczas studiów w Seminarium Duchownym w Poznaniu został inicjatorem Związku Księży Abstynentów na archidiecezje gnieźnieńską i poznańską i idei wstrzemięźliwości pozostał wierny do końca życia. Zaangażował się w prace Towarzystwa Czytelni Kobiet, działał ponadto w Towarzystwie Przemysłowców i Rzemieślników. Prowadził również pracę pedagogiczną i kulturalną z młodzieżą jako dyrektor gimnazjum w Gostyniu, którego był inicjatorem. Po drugiej wojnie zainicjował powstanie Domu Starców im. Matysiaków w Warszawie. V. Lewandowicz, Nota biograficzna ks. Franciszka Olejniczaka, s. 1-28, strona internetowa http://www.zasina.net/olejniczak/pliki/lewandowicz.pdf [dostęp: 16 października 2012 r.].

${ }^{4}$ Kazimierz Niesiołowski (1872-1949), kapłan katolicki, długoletni proboszcz parafii pw. Ścięcia Św. Jana Chrzciciela w Pleszewie, działacz społeczny, oświatowy i abstynencki. Pierwszy prezes Związku Księży Abstynentów w archidiecezji gnieźnieńskiej i poznańskiej, współzałożyciel Towarzystwa Zupełnej Wstrzemięźliwości od Napojów Alkoholowych „Wyzwolenie”, wiceprezes Katolickiego Związku Abstynentów, członek Zarządu Głównego Polskiej Ligii Przeciwalkoholowej. Ksiądz Niesiołowski był redaktorem czasopisma abstynenckiego „Miesięcznik dla Popierania Ruchu Wstrzemięźliwości”, który od 1911 r. wychodził jako „Świt. Miesięcznik dla Popierania Ruchu Wstrzemięźliwości”. M. P. Romaniuk, Ksiądz Kazimierz Niesiołowski (1872-1949), [w:] W trosce o trzeźwość Narodu. Sylwetki najwybitniejszych działaczy trzeźwościowych XIX i XX wieku oraz antologia ich pism, t. 2, red. tenże, Warszawa 1996, s. 265, 269.

5 K. Dąbrowski, Ksiądz prałat Henryk Antoni Szuman..., s. 44; A. Gulczyński, Ks. prałat Kazimierz Niesiołowski 1872-1949, Pleszew 1995, s. 37.

${ }^{6}$ Od 1909 r. był sekretarzem oddziału Związku Księży Abstynentów w diecezji chełmińskiej. 
wał z założonym w 1906 r. przez jezuitę ks. Mieczysława Kuznowiczaㄱ, Związkiem Młodzieży Przemysłowej i Rękodzielniczej pod Wezwaniem św. Stanisława Kost$\mathrm{ki}^{8}$, która to organizacja zasłynęła z prowadzonych kampanii antyalkoholowych i antynikotynowych wśród galicyjskiej młodzieży rzemieślniczej i robotniczej ${ }^{9}$. Po ukończeniu studiów w Krakowie był ks. Szuman wikariuszem w Nidzicy i Wielu oraz proboszczem w Trzebczu i Nawrze, a od 1932, aż do męczeńskiej śmierci w 1939 roku pełnił obowiązki proboszcza w Starogardzie i funkcję dziekana starogardzkiego (1937-1939) ${ }^{10}$.

Choć ks. Szuman nie był dobrym mówcą, to jednak dał się poznać i zapamiętany został jako społecznik, który potrafił oddziaływać na innych swoją silną osobowością. Jak wspomina ks. Bernard Sychta: „W tej dziedzinie był wzorem i ideałem niedoścignionym. Potrafił całkowicie tej pracy się poświęcić. Tu znajdował radość życia, tu czuł się szczęśliwy i zadowolony"11.

Ksiądz Henryk Szuman był członkiem wielu polskich organizacji charytatywnych i oświatowych, np. Towarzystwa Naukowego w Toruniu czy Towarzystwa Czytelni Ludowych na powiat chełmiński. W maju 1918 r. założył i był długoletnim prezesem Pomorskiego Towarzystwa Opieki nad Dziećmi z siedzibą w Toruniu. Współorganizatorką Towarzystwa, którego celem była opieka nad dziećmi osieroconymi i opuszczonymi oraz kształcenie kadr zawodowych ochroniarek dla przedszkoli i sierocińców, była siostra ks. Henryka Szumana - Wanda ${ }^{12}$. Zadaniem Pomorskiego Towarzystwa Opieki nad Dziećmi było nie tylko ratowanie polskich sierot przed opuszczeniem, lecz także utrata przez nie uczuć patriotycznych i wiary, co stanowiło rezultat ich przebywania w niemieckich placówkach opiekuńczo-wychowawczych ${ }^{13}$. Ponadto z myślą o bezdomnych dzieciach z kresów, sierotach wojennych zorganizował ks. Szuman w Toruniu w 1920 r. dla 20 opuszczonych dzieci Sierociniec im. gen. Hallera, który w późniejszym okresie swą sie-

7 Mieczysław Józef Kuznowicz (1874-1945), jezuita, organizator katolickich zrzeszeń młodzieży robotniczej i rzemieślniczej. W 1906 r. zorganizował w Krakowie Związek Młodzieży Przemysłowej i Rękodzielniczej pod Wezwaniem św. Stanisława Kostki, którego celem było katolickie i patriotyczno-obywatelskie wychowanie młodzieży pracującej i uczącej się rzemiosła oraz podnoszenie jej kwalifikacji zawodowych i zapewnienie właściwej rozrywki. T. Dalewski, Kuznowicz Mieczysław Józef, [w:] Polski Słownik Biograficzny, t. 16, Wrocław [i in.] 1971, s. 320-321.

8 Początków Związku należy doszukiwać się w istniejącym od 1896 r. we Lwowie towarzystwie (patronacie) zwanym Opieką św. Stanisława Kostki, zorganizowanym z inicjatywy ks. Błażeja Szydłowskiego. O działalności Związku Młodzieży Przemysłowej i Rękodzielniczej pod Wezwaniem św. Stanisława Kostki na rzecz walki z alkoholizmem zob. szerzej: I. Krasińska, Z problematyki walki z alkoholizmem wśród młodzieży galicyjskiej w początkach XX wieku, [w:] Galicja i jej dziedzictwo, t. 20: Historia wychowania misja i edukacja. Profesorowi Andrzejowi Meissnerowi w 70. rocznice urodzin i 45-lecia pracy naukowej i nauczycielskiej, red. K. Szmyd, J. Dybiec, Rzeszów 2008, s. 518-521.

9 O swoich kontaktach z ks. Mieczysławem Kuznowiczem i zorganizowanym przez niego Związku pisał również sam ks. Szuman na łamach redagowanego przez siebie miesięcznika. Zob.: H. Szuman, Kółko abstynentów w Krakowie, „Nasz Przewodnik” (dalej: NPrz) 1915, nr 8, s. 62.

10 H. Mross, Szuman Henryk..., s. 246; B. Sychta, Wspomnienia pośmiertne. Śp. X. prałat Henryk Szuman, „Orędownik Diecezji Chełmińskiej” 1947, t. 3, s. 478; K. Ossowski, Wierny Chrystusowi i Ojczyźnie. Sługa Boży ksiądz Antoni Henryk Szuman, Pelplin 2012, s. 26-36.

11 B. Sychta, Wspomnienia..., s. 479.

12 Na temat Wandy Szuman zob. m.in. A. Wałęga, Życie i działalność Wandy Szuman (18901994), Toruń 2005.

13 O działalności Pomorskiego Towarzystwa Opieki nad Dziećmi pisze m.in. A. Wałęga, Działalność opiekuńcza Pomorskiego Towarzystwa Opieki nad Dziećmi (1918-1948), [w:] Virginibus..., s. 131-144. 
dzibę posiadał we wsi Ostrowite koło Golubia. Z własnych funduszy zorganizował i wspierał kolonie nad morzem, które odbywały się corocznie w latach 1920-1939 w Gdyni. Z tego typu wypoczynku w skali roku skorzystać mogło nawet 1200 dzieci $^{14}$.

Nie zapominał ks. Szuman również o starszych, zakładając z myślą o nich w Nawrze Stowarzyszenie Ojców i Matek. Do zadań chrześcijańskich ojców należało pielęgnowanie wiary w życiu publicznym, a chrześcijańskie matki skupione w Stowarzyszeniu odpowiedzialne były za pogłębianie chwały Bożej w życiu rodzinnym ${ }^{15}$.

W okresie międzywojennym był ks. Henryk Szuman członkiem Rady Opieki Społecznej w Warszawie, przy Ministerstwie Pracy i Opieki Społecznej. Będąc natomiast proboszczem w Starogardzie, przyczynił się do rozwoju "Caritasu”. W uznaniu licznych zasług otrzymał godność prałata oraz odznaczony został orderem „Polonia Restituta”. Zginął śmiercią męczeńską 2 października 1939 r. w Fordonie, gdzie zamieszkał u swojego przyjaciela ks. Józefa Szydzika ${ }^{16}$, po tym jak Niemcy zajęli Starogard ${ }^{17}$.

Podsumowując działalność społeczną i charytatywną prowadzoną przez ks. Henryka Szumana, warto odwołać się do fragmentu wspomnień o nim pióra Witolda Szumiato: „Nigdy nie liczył na wdzięczność tych, którym pomagał, chociaż bardzo bolał nad zdarzającymi się wypadkami niewdzięczności. Cała akcja charytatywna skupiała się w jego ręku, toteż bywało nieraz, że odpowiedzialność za niedociągnięcia opieki społecznej starano się przerzucić na jego osobę. Jednak te wypadki nigdy nie zniechęcały ks. Szumana. W bliźnim widział swojego brata i odbicie Chrystusa. To było dla niego bodźcem do ofiarności i oddania, miłości i zaangażowania się bez reszty"18.

\section{Działacz abstynencki}

Równolegle z pracą kapłańską i duszpasterską oraz z działalnością społeczną prowadził ks. Szuman akcję na rzecz abstynencji. Już sam fakt, że był duchownym, skutkował wygłaszaniem przez niego na tematy wstrzemięźliwości stosownych kazań czy nauk kościelnych podczas rekolekcji parafialnych oraz indywidualnych pogadanek, np. podczas wizyt duszpasterskich w domach wiernych. Ponadto wygłaszał cykle wykładów i odczytów na ten temat i organizował stosowne wystawy. W 1911 r. ks. Henryk Szuman wziął udział w XIII Międzynarodowym Kongresie Przeciwalkoholowym w Scheveningen (dzielnica Hagi) ${ }^{19}$, zaś

${ }^{14}$ A. Wałęga, Ksiądz Henryk Antoni Szuman..., s. 170-171; H. Mross, Szuman Henryk..., s. 246; J. Milewski, Przyjaciel dzieci, „Pomerania” 1984, nr 2, s. 37.

15 K. Dąbrowski, Ksiądz prałat..., s. 47; K. Ossowski, Wierny Chrystusowi i Ojczyźnie..., s. 30.

16 Józef Szydzik (1871-1939), kapłan katolicki, działacz społeczny, polityczny, gospodarczy. Działał m.in. w Towarzystwie Czytelni Ludowych, był współzałożycielem i dyrektorem Banku Ludowego w Wielu i delegatem do Polskiego Sejmu Dzielnicowego w Poznaniu. B. B. Wróblewski, Józef Szydzik, [w:] Korporacja Akademicka "Capitolia” (Kraków), strona internetowa http://www.archiwumkorporacyjne.pl/index.php/muzeum-korporacyjne/krakow/k-capitolia/ [dostęp: 9.10.2012].

17 H. Mross, Szuman Henryk..., s. 246.

18 W. Szumiato, Wspomnienie o ks. Henryku Szumanie, „Przewodnik Katolicki” 1971, nr 11, s. 95.

19 O tym kongresie zob.: B. Leonhard, Kongresy niosące nadzieję, „Zdrowie i Trzeźwość” 1978, nr 9, s. 5; I. Krasińska, Kongresy przeciwalkoholowe w Galicji w latach 1904-1912, „Studia Historycz- 
w 1934 r. w Polskim Kongresie Przeciwalkoholowym w Krakowie, gdzie wygłosił odczyt pt. Co przemawia za osobistą abstynencją kapłana. Przez kilka lat pełnił ponadto obowiązki prezesa Koła Związku Księży Abstynentów Diecezji Chełmińskiej. Natomiast na polecenie ks. bpa chełmińskiego Stanisława Wojciecha Okoniewskiego 20 ułożył ks. Henryk Szuman, zatwierdzony 5 listopada 1931 r., „Statut Bractw i Związku Bractw Wstrzemięźliwości pod opieką M.[atki] Bożej Gromnicznej w Diecezji Chełmińskiej"21.

Choć ks. Szuman sam był żarliwym abstynentem, nie spożywał napojów alkoholowych i nie palił papierosów, a zarazem pragnął widzieć wszystkich zwolennikami ruchu abstynenckiego, to jednak w tych drażliwych nieraz kwestiach był niezwykle delikatny, wyrozumiały i taktowny, potrafił bowiem uszanować poglądy innych, nie zmuszając nikogo do zachowywania wstrzemięźliwości²2.

Z myślą o najmłodszych abstynentach rozpoczął też ks. Henryk Szuman redagowanie i wydawanie „Naszego Przewodnika”. Idea jego powstania zrodziła się już pod koniec 1912 r., czyli wkrótce po powrocie ks. Szumana ze studiów w Krakowie. Pierwszy okazowy numer "Naszego Przewodnika” ukazał się w styczniu roku następnego i jak przyznał ks. Szuman, gdyby nie pomoc okazana mu przez ks. Hieronima Gołębiewskiego ${ }^{23}$ w przygotowaniu do druku i rozpowszechnianiu tego numeru, być może nigdy nie odważyłby się na wydawanie pisemka ${ }^{24}$.

ne" 2009, z. 2, s. 116. O uczestnictwie w tym kongresie pisał również sam ks. Szuman na łamach pisemka w tekście: Co lalka chciała na kongresie?, NPrz, 1915, nr 5, s. 38-39.

20 Stanisław Wojciech Okoniewski (1870-1944), ksiądz katolicki, biskup diecezji chełmińskiej, historyk i biblista. W latach 1902-1907 wydawał „Przegląd Kościelny” i działał na niwie społecznej i oświatowej. Z jego inicjatywy rozpoczęto wydawanie (1929 r.) „Miesięcznika Diecezji Chełmińskiej”, dokonał również zreformowania tamtejszego seminarium duchownego, zreorganizował sieć parafialną i administrację diecezji, założył Muzeum Diecezjalne, organizował z myślą o duchowieństwie kongresy i kursy. L. Grzebień, Okoniewski Stanisław Wojciech, [w:] Słownik polskich teologów katolickich 1918-1981, t. 6: K-P, red. L. Grzebień, Warszawa 1983, s. 580-581.

${ }^{21}$ Pełny tekst Statutu dostępny jest m.in. w tygodniku „Wiadomości Kościelne” - gazecie przeznaczonej dla parafii dekanatu chełmżyńskiego, której redaktorem był ks. Józef Szydzik. Szerzej: „Wiadomości Kościelne” 1932, nr 3, s. 10-11.

22 H. Mross, Szuman Henryk..., s. 246; B. Sychta, Wspomnienia..., s. 480; A. Wałęga, Ksiądz Henryk Antoni Szuman..., s. 169-170; taż, Życie i działalność..., s. 33; Tradycje abstynenckie w Polsce, [w:] Wesele wesel. XVIII ogólnopolskie spotkanie małżeństw, które miały wesela bezalkoholowe. Kraków 2.8-5.8 2012, http://weselewesel.lap.pl/oWeselachBezalkoholowych.dlaczego.tradycja.html [dostęp: 5.10.2012].

${ }^{23}$ Hieronim Gołębiewski (1845-1918), kapłan katolicki, działacz oświatowy i abstynencki. Święcenia kapłańskie przyjął w 1868 r. w Pelplinie. Był m.in. proboszczem w Jastarni i Szynwałdzie. W Jastarni zainteresował się życiem i pracą rybaków i napisał nawet kilka prac im poświęconych. W 1889 r. założył w Szynwałdzie bractwo trzeźwości. Działał także w Towarzystwie Czytelni Ludowych, gdzie pełnił funkcję bibliotekarza oddziału tej organizacji w Jastarni. Od 1875 r. związany był z Towarzystwem Naukowym w Toruniu i przez pewien czas pełnił funkcje sekretarza zarządu i skarbnika. Działał również w Towarzystwie Wiecowym, którego celem było rozpowszechnianie polskiej oświaty elementarnej. A. Bukowski, Gołębiewski Hieronim, [w:] Polski Słownik Biograficzny, t. 8, Wrocław-Kraków-Warszawa 1959-1960, s. 248-249; H. Mross, Słownik biograficzny kapłanów diecezji chełmińskiej wyświęconych w latach 1821-1920, Pelplin 1995, s. 81-82.

${ }^{24}$ W. Theiss, Troska i nadzieja. Działalność społeczno-wychowawcza ks. Henryka Szumana na Pomorzu w latach 1908-1939, Toruń 2012, s. 108-109; tenże, Ks. Henryk Szuman - redaktor „Naszego Przewodnika” (1913-1919), [w:] Myślenie i działanie pedagoga. Opracowanie dedykowane 


\section{„Nasz Przewodnik” - powstanie i rozwój pisemka}

Wkrótce po ukazaniu się pierwszego numeru do wydawcy i redaktora zaczęło napływać szereg listów od wdzięcznych czytelników. W jednym z nich ks. S. K. Jaranowski powiadamiał ks. Szumana, że zainicjowane przez niego pisemko „«Nasz Przewodnik» jest dzieciom [...] rzeczywistym przewodnikiem. Ziarno rzucone przezeń w serce dziecięce plon obfity wydaje [...]. Jako kierownik Bractwa Abstynenckiego Dzieciątka Jezus stwierdziłem, że dzieci z niego dużo korzystają. Przez deklamację i śpiewy uczą się [...] kochać co dobre i szlachetne - Boga i ojczyznę swoją. Niech wszyscy dopomogą do tego, żeby «Nasz Przewodnik» dotarł do każdej chociaż najuboższej chatki, gdzie są polskie dzieci i gromadził je w Bractwach Abstynenckich. Zapłatę za te trudy już tu na ziemi odbieramy widząc jak dziatwa polska rośnie zdrowa na ciele i na duszy [...]"25.

Szczególne znaczenie dla redaktora i wydawcy miesięcznika miał zapewne list od ks. Kuznowicza z Krakowa, od którego ks. Szuman w czasach swych studiów na Uniwersytecie Jagiellońskim wiele nauczył się w zakresie szerzenia abstynencji wśród młodocianych i z którym na tym polu owocnie współpracował. W liście tym czytamy: „Nie mam słów wdzięczności za to pożyteczne pisemko, które jest wprost znakomicie redagowane. Niech Bóg pobłogosławi”26.

W czasach, kiedy redaktorem i wydawcą „Naszego Przewodnika” był ks. Szuman, pismo ukazywało się z reguły raz w miesiącu. Wyjątek stanowił podwójny numer 9-10 (wrzesień-październik), który wyszedł drukiem w 1914 r. Redaktor poinformował o tym czytelników i prenumeratorów we wstępnym wierszyku, a jako przyczynę podał wybuch wojny, prosząc jednocześnie Matkę Boską o łaskę, opiekę i wstawiennictwo u Jezusa dla narodu polskiego, a zwłaszcza dla dzieci, w tych trudnych chwilach wojennej pożogi ${ }^{27}$. Skumulowane numery ukazały się również w 1919 r., a więc w ostatnim roku, kiedy redaktorem i wydawcą był ks. Szuman ${ }^{28}$. Spowodowane było to nadmiarem zajęć i obowiązków kapłańskich oraz działalnością społeczną założyciela miesięcznika.

Objętość jednego numeru wynosiła średnio 8 stron, a więc objętość rocznika dochodziła do 100 stron. Numer pierwszy poprzedzał z reguły spis treści (spis rzeczy) rocznika. Pismo miało układ działowy i w latach 1915-1918 liczba działów była w zasadzie niezmienna ${ }^{29}$ : I. Pogadanki, II. Powiastki i przykłady,

prof. zw. dr. hab. Zdzisławowi Kosyrzowi z okazji 50-lecia pracy naukowej, red. M. Konopczyński, J. Kunikowski, S. Tomiuk, Warszawa 2009, s. 74-75.

${ }^{25}$ Cyt. za: J. Sajewicz, Głos mają sieroty. Życie i działalność wielkiego opiekuna sierot ks. prałata Henryka Antoniego Szumana proboszcza Starogardzkiego zamordowanego w Fordonie w 1939 r., Londyn 1985, s. 55-56.

26 Tamże, s. 56.

27 Ks. red. [H. Szuman], Na październik r. 1914, NPrz, 1914, nr 9 i 10, s. 65.

${ }^{28}$ Numer 6 i 7 za czerwiec i lipiec, 8 i 9 za sierpień i wrzesień oraz 10-12 za październik, listopad i grudzień.

${ }^{29}$ W latach 1913-1914 miesięcznik podzielony był na dziewięć działów: I. Rozrywki, II. Powiastki, III. Wiersze, IV. Komedyjki, V. Pieśni, VI. Zabawy i zajęcia domowe, VII. Zagadki, VIII. Powinszowania, IX. Rozmaitości. 
III. Wiersze, IV. Pieśni, V. Teatrzyki, VI. Powinszowania, VII. Gry i zajęcia domowe, VIII. Rozmaitości, IX. Abstynenckie Bractwo Dzieciątka Jezus, X. Zagadki i łamigłówki, XI. Złote słówka i wskazówki, XII. Kącik listowy (Kącik liścików, Kącik liścików i ofiarek na sierotki), XIII. Składki na głodne dzieci (Ofiarki na głodne dzieci, Składki na głodne sierotki w Królestwie). Rocznik VII za 1919 r. był objętościowo skromniejszy i liczył 68 stron. W latach 1914-1919 „Nasz Przewodnik” posiadał 15 000-20 000 abonentów. W okresie zaborów i pierwszej wojny docierał do Galicji, Królestwa Polskiego, Księstwa Poznańskiego, na Śląsk, Pomorze oraz do prenumeratorów zagranicznych, a głównie do Polaków przebywających w Ameryce oraz w Westfalii i Nadrenii ${ }^{30}$.

Zachęcając najmłodszych czytelników do poszanowania zakupionego pojedynczego numeru miesięcznika oraz do jego systematycznej prenumeraty, ks. Szuman pisał m.in.: „Każda rodzina, każda dziecina, każdy młody abstynent, każdy harcerz szkolny powinni abonować miesięcznik obrazkowy pt. «Nasz Przewodnik»" 31 . Po takich słowach zachęty odzew był duży i już w 1913 r. „Nasz Przewodnik" doczekał się 10000 prenumeratorów, dla których stał się niezwykle pomocnym narzędziem wychowawczym i rozrywkowym ${ }^{32}$.

Ponadto ks. Szuman prosił czytelników, aby nadsyłali do redakcji listy z opiniami o wydawanym z myślą o nich miesięczniku. Listy od czytelników i odpowiedzi na nie publikowane były w osobnym dziale: Kącik liścików, Kącik listowy, Kącik liścików i ofiarek na sierotki, Listy czytelników do ks. redaktora. W dziale tym znalazły się m.in. interesujące korespondencje dotyczące nowo powstałych lub już istniejących dziecięcych bractw abstynenckich. Nadsyłali je ich członkowie lub opiekunowie. Drogą korespondencji z czytelnikami redaktor i wydawca inicjował też „[...] różnego rodzaju działania i akcje, zachęcał do pracy nad sobą, przestrzegał przed niebezpieczeństwami i błędami, uczył religii i miłości do ojczyzny. Unikał przy tym moralizatorstwa, nigdy też nie wypowiadał się z pozycji formalnych i autorytatywnych, co nie znaczy, że był pobłażliwy i nadmiernie wyrozumiały. Udanie łączył subtelność i stanowczość"33.

W czasach, kiedy wydawcą i redaktorem pisemka był ks. Henryk Szuman, redakcja i administracja znajdowała się początkowo w miejscowości Wiele na Pomorzu, a od lipca 1914 do grudnia 1919 r. w Trzebczu (poczta Nawra). Drukowała je Drukarnia „Praca” w Poznaniu. „Nasz Przewodnik” można było zamawiać w dziale ekspedycji, mieszczącym się początkowo przy Drukarni „Praca” (ulica Rycerska 38), a od listopada 1913 r. dział ten przeniesiony został na ulicę Piekary 20/21. Ekspedycją pisma w Galicji zajmowało się przez pewien okres Towarzystwo Zupełnej Wstrzemięźliwości od Napojów Alkoholowych „Eleuteria - Wyzwolenie" w Krakowie z siedzibą przy ulicy św. Marka 23. Można je było również zamawiać w Zakopanem w Wilii „Słoneczna”. Pieczę i nadzór nad pisemkiem

30 J. Janiszewski, Od nowej redakcji, NPrz, 1920, nr 85, 86, s. 1.

31 [Każda rodzina...], NPrz, 1919, nr 10-12, s. 68.

32 "Nasz Przewodnik”, „Świt” 1913, nr 121, s. 288.

${ }^{33}$ W. Theiss, Troska i nadzieja..., s. 110. 
od początku jego ukazywania się objął oddział Związku Księży Abstynentów dla diecezji chełmińskiej, którego ks. Szuman był aktywnym działaczem.

Za pojedynczy numer w 1913 r. należało zapłacić w Wielkopolsce i na Pomorzu 4 fenigi, a w Galicji 4 halerze. Prenumerata roczna dla Wielkopolski i Pomorza wynosiła 30 fenigów, w Galicji 40 halerzy, w Królestwie Polskim 20 kopiejek, a 10 centów w Ameryce. W 1915 r. prenumerata półroczna wynosiła analogicznie 20 fenigów, 30 halerzy, 15 kopiejek, 5 centów; w 1917 r. (przedpłata roczna): 40 fenigów, 60 halerzy, 30 kopiejek. W roku 1919 za roczną prenumeratę na terenie kraju należało zapłacić markę polską. Można było również nabywać już oprawiony miesięcznik ( $w$ formie rocznika) w cenie 90 fenigów (z przesyłką opłata wynosiła 1 markę). Redakcja zachęcała do tego abonentów, pisząc w grudniu 1916 r.: „Niejeden z czytelników zagubił ten lub ów numerek, drugi niechcący poplamił lub podarł. Kto swoją ukochaną gazetę chce posiąść w nowej trwałej sukience, ze spisem rzeczy, by móc każdego czasu zajrzeć do niej i łatwo wszystko odszukać, niech nadeśle 1 markę [...]"34. Jedynie numer okazowy był bezpłatny i można go było otrzymać w każdej ilości, po wcześniejszym złożeniu stosownego zamówienia w Poznaniu w dziale ekspedycji.

„Nasz Przewodnik” był pismem bogato ilustrowanym. Uwagę zwraca już sama winieta do numeru 6 z 1913 r., która wyobrażała dwoje dzieci na tle górzystego krajobrazu z krzyżem w oddali. Jedno z dzieci klęczące na ziemi w ręku trzymało butelkę.

Zmiana winiety nastąpiła w lipcu 1913 r., o czym powiadamiał czytelników redaktor i wydawca: „Dziatki kochane! Gazetka nasza przywdziała nową sukienkę, czyli nowy obrazek tytułowy. [...]. «Nasz Przewodnik» staje się coraz ładniejszy i coraz więcej dobrego dzieciom przynosi, to też pokochajcie pisemko Wasze coraz mocniej i doglądajcie pilnie, aby rzeczywiście na ziemiach polskich nie było chłopczyka bez «Przewodnika», nie było dzieweczki bez tej książecz$\mathrm{ki}^{\prime \prime}$. Nowa winieta wyobrażała Chrystusa w otoczeniu dzieci ubranych w narodowe polskie stroje. Wokoło Chrystusa błogosławiącego dzieci widać pola, drzewa, wody, chaty włościańskie, a w oddali kościół. Jak podkreślał ks. Szuman, była to świątynia parafialna w Wielu, gdzie wówczas mieściła się redakcja pisemka. U dołu winiety z lewej jej strony znajdowała się wijąca się żmija, wokół kielicha wypełnionego alkoholem, a po prawej stronie szklanka czystej, świeżej i zdrowej wody, a obok niej dojrzałe, soczyste owoce. Winieta ta zdobiła pisemko do czerwca $1915 \mathrm{r}$.

Od lipca do listopada $1915 \mathrm{r}^{36}$ winieta przedstawiała siedzących przy stole dorosłych (rodziców), z których mężczyzna czytał, a kobieta pisała, a na podłodze dwoje dzieci, z których jedno grzecznie się bawiło, a drugie czytało.

Kolejna zmiana winiety nastąpiła w styczniu $1916 \mathrm{r}$. i obowiązywała do grudnia tegoż roku. Wyobrażała ona kilkuletniego Jezusa trzymającego w dłoni krzyż, który

\footnotetext{
${ }^{34}$ [H. Szuman], „Nasz Przewodnik” oprawny, NPrz, 1916, nr 12 (gwiazdkowy), s. 100.

${ }^{35}$ [H. Szuman], Nasz nowy obrazek, NPrz, 1913, nr 7, s. 49-50.

36 Numer grudniowy za 1915 r. przyozdabiała okolicznościowa (świąteczna) winietka.
} 
stopami miażdżył smoka (symbol szatana i grzechu). Jezusa otaczało ośmioro dzieci, z których każde w ręku trzymało lilię (symbol czystości i niewinności). $\mathrm{U}$ dołu winiety w prawym jej rogu widniał szkic kościoła parafialnego w Grzybnie, gdzie powstało pierwsze na Pomorzu abstynenckie Bractwo Dzieciątka Jezus. Natomiast lewy jej róg zdobił szkic poznańskiego ratusza z polskim orłem na wieży ${ }^{37}$. Winietka ta uatrakcyjniała pisemko również w latach 1919-1920, z tym że wówczas zamiast szkiców świątyni w Grzybnie i poznańskiego ratusza u dołu widniał symbol odrodzonego państwa polskiego, czyli godło (orzeł w królewskiej koronie).

W latach 1917-1918 „Nasz Przewodnik” okresowo powracał do znanych już winiet. W tym czasie zdarzały się również numery, które nie zostały zaopatrzone w tego typu ozdobniki. Oprócz rysunku winieta zawierała najczęściej tytuł i podtytuł pisma, adres administracji, spis treści danego numeru, a w początkowym okresie ukazywania się również motto (hasło przewodnie) pisma brzmiące:

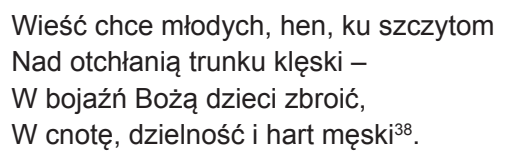

Obok atrakcyjnej i bogato zdobionej winiety, liczne ilustracje znajdowały się w tekście głównym. Wyobrażały one najczęściej: Jezusa Chrystusa, Najświętszą Maryję Pannę, świętych aniołów stróżów, świętych i błogosławionych Kościoła katolickiego, bohaterów narodowych (Tadeusza Kościuszkę, gen. Jana Henryka Dąbrowskiego), pisarzy i poetów (Adama Mickiewicza, Henryka Sienkiewicza), dzieci oraz wesołe (ośmieszające) scenki z udziałem osób w stanie nietrzeźwym czy palących papierosy, cygara lub fajki. Ponadto wraz z korespondencjami do redakcji nadchodziły fotografie z ochronek, sierocińców oraz nowo powstałych lub istniejących dziecięcych towarzystw abstynenckich, czyli Bractw Dzieciątka Jezus i Związków Anioła Stróża. Fotografie upiększały i uatrakcyjniały tekst, jak również go dokumentowały.

\section{Zawartość treściowa pisemka}

Większość tekstów zamieszczanych na łamach miesięcznika „Nasz Przewodnik" pisał sam ks. Szuman, a w późniejszym okresie (1920 r.) ks. Janiszewski. W pisemku publikowane były również teksty innych twórców, np.: Adama Mickiewicza, Marii Konopnickiej, Władysława Bełzy, Stanisława Jachowicza, Heleny

${ }^{37}$ Ks. red. [H. Szuman], Nasz Przewodnik. (Do nowego obrazka tytułowego), NPrz, 1916, nr 1, s. 2.

38 Przykładowo numer okazowy, 2, 4, 5, 6 z 1913 r. 
Bocheńskiej, Pauli Wężyk ${ }^{39}$, Marii Goreckieje, Wandy Szuman oraz Wandy Brzeskiej ${ }^{41}$ - autorki podpisującej się pseudonimem „Wujek Zbigniew” lub rzadziej „Zbigniew Topór” czy „Jan Pałucki”. Występowały również teksty będące przedrukami z prasy i książek. Ksiądz redaktor dbał jednak o prawa autorskie i życzył sobie, aby każdy przedruk zaopatrzony był w stosowny odsyłacz kierujący czytelnika do pierwotnego źródła.

Obok zwykłych numerów „Naszego Przewodnika” ks. Szuman wydawał również numery okolicznościowe. I tak w numerze pierwszym, czyli okazowym, prosił czytelników o życzliwe przyjęcie nowego pisemka oraz wyjaśniał powody, jakie skłoniły go do rozpoczęcia jego wydawania ${ }^{42}$. Okolicznościowe (gwiazdkowe) numery „Naszego Przewodnika” ukazywały się w styczniu 1914 r. oraz w grudniu w latach 1915-1917. Wychodziły również numery wakacyjne w lipcu 1916 i 1917 r.

W 1916 r. sporo miejsca na łamach pisemka poświęcono Henrykowi Sienkiewiczowi. W numerze $5 \mathrm{z}$ maja tegoż roku ukazał się artykuł przygotowany z okazji 70. rocznicy urodzin pisarza. Ksiądz Szuman po zwięzłym przedstawieniu jego życia i twórczości podkreślił zasługi twórcy (przebywającego wówczas w Szwajcarii) na rzecz bezdomnych Polaków, a zwłaszcza chorych i głodnych dzieci z Królestwa Polskiego. W artykule zachęcał dzieci z Wielkopolski i Pomorza, a zwłaszcza najmłodszych zrzeszonych w abstynenckich Bractwach Dzieciątka Jezus, aby za przykładem Sienkiewicza rozpoczęły zbiórkę pieniędzy na potrzeby swych biednych rówieśników. Zebraną kwotę w wysokości 400 marek

39 Paula Wężyk (1876-1963), poetka, działaczka społeczna i charytatywna, zwłaszcza wśród młodzieży. Współpracowała z wieloma czasopismami: „Przewodnikiem Katolickim”, „Pracą”, „Głosem Wielkopolskim”, „Dziennikiem Poznańskim”, „Kurierem Poznańskim”, „Wielkopolaninem”, „Naszym Misjonarzem”, „Małym Misjonarzem”, „Murzynkiem”. Przez kilka lat redagowała pismo dla gospodyń wiejskich „Dobra Gospodyni”. Paula Wężyk wydała kilkanaście zbiorów opowiadań i wierszy oraz napisała kilka utworów scenicznych z myślą o dziecięcych teatrzykach. W 1934 r. została odznaczona medalem przez Polską Akademię Literatury. H. Tyszkiewicz, Życie i twórczość Pauli Wężyk, [w:] Ziemia kępińska. Historia miejscowości powiatu kępińskiego, http://henryktyszkiewicz.w.interia.pl/paula. html [dostęp: 9.10.2012].

40 Maria Helena Julia Gorecka (1835-1922), pisarka i działaczka filantropijna, córka Adama Mickiewicza, żona Tadeusza. Uzdolniona w muzyce i rysunku. Choć całe życie spędziła za granicą, nie zapomniała o ojczystym kraju. Była członkiem Towarzystwa im. Klaudii Potockiej, które zajmowało się niesieniem pomocy potrzebującym rodakom na obczyźnie. Gorecka napisała książkę na podstawie opowiadań ojca i własnej pamięci Wspomnienie o Adamie Mickiewiczu. Opowiedziane najmłodszemu bratu. Na język francuski przetłumaczyła kilka utworów Sienkiewicza. Współpracowała m.in. z „Kroniką Rodzinną". B. Monkiewiczówna, Gorecka Maria Helena Julia, [w:] Polski Słownik Biograficzny, t. 8, Wrocław-Kraków-Warszawa 1959-1960, s. 305.

41 Wanda Brzeska, pseud. „Jan Pałucki”, „Wujek Zbigniew” i „Zbigniew Topór” (1893-1978), powieściopisarka, poetka, etnograf. Studiowała na Uniwersytecie Poznańskim i tam też w 1926 r. uzyskała doktorat. Pisywała wiersze i powieści dla dzieci, powieści dokumentalne, nowele. Była również autorką kilku prac o charakterze naukowym. Redagowała dodatek literacki do „Dziennika Poznańskiego” pt. „Kultura i Sztuka”. Angażowała się również w działalność polityczną. W okresie okupacji hitlerowskiej mieszkała m.in. w Warszawie, gdzie prowadziła tajne nauczanie. Po zakończeniu wojny pracowała na uniwersytetach w Poznaniu i Toruniu. Była członkiem oddziału Związku Literatów Polskich w Toruniu. S. Bilski, Brzeska Wanda, [w:] Słownik biograficzny regionu brodnickiego, BrodnicaToruń 1991, s. 22-23.

42 H. Szuman, Do dzieci!, NPrz, 1913, nr 1, s. 1-2. 
przekazał następnie ks. Szuman arcybiskupowi gnieźnieńskiemu i poznańskiemu ks. Edmundowi Dalborowi ${ }^{43}$, który za pośrednictwem „Naszego Przewodnika”, 15 lipca 1916 r., podziękował darczyńcom i udzielił im pasterskiego błogosławieństwa. W numerze 12 (gwiazdkowym) redakcja powiadamiała natomiast o śmierci noblisty (16 listopada 1916 r.) i jeszcze raz przypominała jego zasługi na rzecz dotkniętych wojną rodaków ${ }^{44}$.

Numer 10, który czytelnicy otrzymali w październiku 1917 r., poświęcony został Tadeuszowi Kościuszce. Przypadła bowiem wówczas (15 października) 100. rocznica jego śmierci. W numerze Kościuszkowskim można znaleźć artykuł przybliżający bohaterskie czyny wielkiego wodza oraz sztukę dramatyczną przeznaczoną do wystawienia przez najmłodszych pt. Tadeusz Kościuszko. Sztukę napisała Wanda Brzeska ${ }^{45}$. Do zaprezentowania sztuki przez dziecięce teatrzyki zachęcał sam redaktor i wydawca, pisząc m.in: „[...] gazetka dzieci «Nasz Przewodnik» numerkiem niniejszym, numerkiem Kościuszkowskim, pragnie rozbudzić w sercach dziatwy tę miłość i cześć dla zmarłego naczelnika, bo wie, że pokochawszy Kościuszkę, pokochają dzieci całym sercem Ojczyznę, pokochają bliźnich, a szczególnie ubogich i nieszczęśliwych, pokochają życie cnotliwe i ofiarne. Gdzie tylko możliwe, odegrajcie, dzieci, teatrzyk pt. Tadeusz Kościuszko, podany w tym numerku"46.

W numerze tym ukazał się również wierszyk autorstwa ks. Symforiana Tomickiego ${ }^{47}$ pt. Tadeusz Kościuszko ${ }^{48}$.

W numerze 2, który dotarł do rąk czytelników w lutym 1919 r., wspominał natomiast ks. Szuman bohaterskiego szewca Jana Kilińskiego, uczestnika powstania kościuszkowskiego, mianowanego przez naczelnika pułkownikiem, ponieważ 29 stycznia tegoż roku minęło 100 lat od jego śmierci ${ }^{49}$.

${ }^{43}$ Edmund Dalbor (1869-1926), kapłan katolicki. W 1915 r. mianowano go arcybiskupem gnieźnieńskim i poznańskim, a w 1919 r. otrzymał nominację kardynalską. Był pierwszym prymasem odrodzonego państwa polskiego. W jego posłudze pasterskiej ważną rolę odegrała działalność charytatywna wśród ofiar wojennych i jeńców oraz tworzenie w Wielkopolsce ruchu chrześcijańsko-społecznego. Po odzyskaniu przez kraj niepodległości przewodniczył pierwszym konferencjom Episkopatu Polski i współuczestniczył w reorganizacji Kościoła w Polsce, którą udało się przeprowadzić w 1925 r. P. Nitecki, Kardynałowie Kościoła w Polsce, Częstochowa 1999, s. 74-75.

44 [H. Szuman], Ku czci Henryka Sienkiewicza dajcie grosz na głodne dzieci!, NPrz, 1916, nr 5, s. 42-43; tenże, Błogosławieństwo Księdza Arcybiskupa, tamże 1916, nr 8, s. 61-62; tenże, Umarł Henryk Sienkiewicz, NPrz, 1916, nr 12 (gwiazdkowy), s. 99.

45 Szerzej: Wujek Zbigniew [W. Brzeska], Tadeusz Kościuszko, NPrz, 1917, nr 10 (Kościuszkowski), s. 75-76, 78.

${ }^{46}$ Ks. red. [H. Szuman], W stuletnią rocznicę zgonu Tadeusza Kościuszki, tamże, s. 74.

47 Józef Roch Symforian Tomicki (1817-1877), kapłan katolicki, działacz społeczno-oświatowy wśród ludu. Za wydawanie pisemka "Szkółka Niedzielna” został aresztowany i przez dwa lata przebywał w więzieniu, gdzie napisał zbiór poezji Kwiaty z więzienia. Ksiądz Tomicki był ponadto autorem książki dla ludu Mądry Wach oraz redaktorem poznańskiego tygodnika katolicko-narodowego przeznaczonego dla stanu średniego pt. „Oświata”. Ks. Symforian Tomicki. Parafia Mikstat, [w:] Osoby w parafii, http://www.parafia-mikstat.pl/posoby/kssymto.html [dostęp: 9.10 .2012 r.]; Ks. Symforian Tomicki (1817-1877), [w:] Parafia św. Jakuba Apostoła w Mogilnie. Biogramy znamienitych kapłanów, http://www.faramogilno.pl/ksstomicki.htm [dostęp: 9.10.2012].

48 X. [S.] Tomicki, Tadeusz Kościuszko, NPrz, 1917, nr 10 (Kościuszkowski), s. 77.

49 Ks. red. [H. Szuman], Szewc - pułkownik Jan Kiliński, NPrz, 1919, nr 2, s. 12. 
Ponadto na łamach miesięcznika przypominano czytelnikom innych wybitnych Polaków oraz świętych i błogosławionych Kościoła katolickiego, m.in.: Władysława Bełzę $e^{50}$, ks. Józefa Poniatowskiego ${ }^{51}$, św. Stanisława Kostkę ${ }^{52}$ - patrona polskiej młodzieży, św. Izydora Oracza ${ }^{53}$ - patrona rolników, św. Jana Chrzciciela ${ }^{54}$ - patrona związków abstynenckich, św. Józefa ${ }^{55}$, św. Augustyna ${ }^{56}$ - biskupa i doktora Kościoła, bł. Imeldę Lambertini ${ }^{57}$ - patronkę dzieci pierwszokomunijnych, Karolinę Kózkównę $e^{58}$ - bohaterską dziewicę, męczennicę, Józefa Chociszewskiego $0^{59}$ - redaktora, wydawcę, pisarza ludowego i działacza oświatowego.

Gros tekstów dotyczyło także kalendarza liturgicznego i przybliżało czytelnikom liczne święta kościelne, takie jak: Boże Narodzenie, Nowy Rok, Wielkanoc, Zesłanie Ducha Świętego, Boże Ciało, Wszystkich Świętych, uroczystości ku czci Matki Boskiej (Gromnicznej, Zielnej, Częstochowskiej, Różańcowej). Znajdowały się także teksty przypominające o zbliżającym się wielkim poście, który poprzedzała środa popielcowa, a kończyły uroczystości związane z poświęceniem ognia w Wielką Sobotę, czy adwencie przygotowującym wiernych do narodzenia Jezusa. Kilka artykułów dotyczyło niedzielnego świętowania. Znalazły się również teksty związane z objawieniami w Lourdes ${ }^{60}$ czy 200. rocznicą koronacji cudownego obrazu Matki Boskiej Częstochowskiej ${ }^{61}$.

Sporo miejsca na łamach „Naszego Przewodnika” przeznaczone zostało na treści najogólniej mówiąc o charakterze popularnonaukowym i popularyzatorskim. W numerze 2 z 1913 r. pojawił się tekst prezentujący jeden z organów wewnętrznych człowieka, a mianowicie serce. W artykule ukazano również negatywne skutki spożywania alkoholu dla sprawnego funkcjonowania tego jakże ważnego narządu62. Natomiast w tekście Czy chcecie długo żyć? ks. Szuman starał się wykazać ujemne skutki spożywania napojów alkoholowych na organizm ludzki. I choć jak dowodził każdy kiedyś umrzeć musi, to jednak przed 40. rokiem życia umierało jego zdaniem najwięcej kelnerów, szynkarzy i piwowarów. Sędziwego zaś wieku dożywali w zdrowiu najczęściej rolnicy i osoby duchowne, ale przede

${ }^{50}$ [H. Szuman], Umarł przyjaciel dziatwy polskiej ś. p. Władysław Bełza, NPrz, 1913, nr 3, s. 22.

${ }^{51}$ [H. Szuman], Książę Józef, NPrz,1913, nr 11, s. 82.

52 Ks. red. [H. Szuman], Święty Stanisław Kostka, NPrz, 1913, nr 11, s. 84-85; Wujek Zbigniew [W. Brzeska], Święty Stanisław Kostka. (13 listopada), tamże, 1917, nr 11, s. 85-86.

53 Wujek Zbigniew [W. Brzeska], Święty Izydor - (15 maja), NPrz, 1916, nr 5, s. 41-42.

54 [H. Szuman], Święty Jan Chrzciciel (24 czerwca), NPrz, 1916, nr 6, s. 46-47.

55 Wujek Zbigniew [W. Brzeska], Św. Józef (19 marca), NPrz, 1917, nr 3, s. 21-22.

${ }^{56}$ [H. Szuman], Św. Augustyn (28 sierpnia), NPrz, 1919, nr 8 i 9, s. 49.

57 [H. Szuman], Bt. Imelda (16 września), NPrz, 1917, nr 9, s. 69-70.

${ }^{58}$ Ks. redaktor [H. Szuman], Ś. p. Karolina Kózkówna, 16-letnia bohaterka, NPrz, 1917, nr 11, s. 86. Artykuł ten uzupełnia list nadesłany od ks. Władysława Mendrali proboszcza z Zabawy koło Tarnowa, a zarazem żarliwego abstynenta, którego parafianką była Kózkówna. W liście tym przeczytać można, iż Karolina Kózkówna była stałą czytelniczką „Naszego Przewodnika”. Zob. szerzej: tamże, s. $86-87$.

59 [H. Szuman], Ś. p. Józef Chociszewski, NPrz, 1914, nr 12, s. 91.

60 Ks. red. [H. Szuman], Matka Boska i Bernadetta, NPrz, 1917, nr 2, s. 12-14.

61 Ks. red. [H. Szuman], W dwuwiekową rocznicę koronacji Obrazu Matki Boskiej Częstochowskiej, NPrz, 1917, nr 9, s. 68-69.

62 [H. Szuman], Jak wygląda serce moje, NPrz, 1913, nr 2, s. 12-13. 
wszystkim abstynenci63. W tym samym nurcie problemowym pozostaje tekst Jak palenie szkodzi zdrowiu, w którym autor zaznaczył, że nikotyna w pierwszej kolejności „psuje krew”, następnie płuca, osłabia żołądek i nerwy: „Z tego więc nauka wyrasta: Nie będziemy palić i - basta" ${ }^{\prime 4}$ !

Wydrukowany został również krótki artykuł, w którym radzono, jak należy oddychać zimą, przebywając na świeżym powietrzu, by uniknąć kataru, przeziębienia, a nawet zapalenia płuc ${ }^{65}$. Natomiast w tekście Jak siedzieć przy czytaniu i pisaniu? redaktor i wydawca podał cenne wskazówki mówiące, że podczas wykonywania tego typu czynności należy zawsze przybierać pozycję wyprostowaną, gdyż garbienie się prowadzi do wad kręgosłupa, bioder, klatki piersiowej, nadweręża wzrok, a nawet może się stać przyczyną suchot ${ }^{6}{ }^{6}$. Do uczniów skierowane były teksty autorstwa Wandy Brzeskiej, a dotyczące najogólniej rzecz ujmując nauki ortografii ${ }^{67}$. Ksiądz Szuman natomiast w jednym ze swych artykułów zachęcał dzieci, aby uczyły się czytać i pisać w ojczystym języku z podręcznika Jana Suchowiaka ${ }^{68}$ Ćwiczenia w polskim pisaniu, który można było nabyć w każdej księgarni w cenie 15 fenigów ${ }^{69}$.

W numerze 4 z 1916 r. pojawił się tekst propagujący nowinki techniczne, a dokładniej aparat fotograficzny, który choć w Polsce był już dość znany, to w Afryce stanowił zupełną nowość i nazywany był tam „czarodziejską szkatułką". Wanda Brzeska autorka artykułu podsumowując tekst, prosiła polskie dzieci, aby zechciały w swych codziennych modlitwach upraszać Boga o łaski i błogosławieństwo również dla swych afrykańskich rówieśników, którym przyszło żyć w biedzie i zacofaniu ${ }^{70}$.

Niezwykle pożyteczne były zapewne teksty typowo praktyczne, a do nich zaliczyć można artykuły ks. Szumana: Jak ratować dziecko, które się załamało na lodzie?, Jak ratować siebie lub innych, gdy się odzież zapali?, O ratowaniu tonących ${ }^{71}$.

Praktyczny charakter posiadał również rymowany tekst zachęcający dzieci i młodzież do zakładania przydomowych ogródków. Ksiądz redaktor podawał

${ }^{63}$ [H. Szuman], Czy chcecie długo żyć?, NPrz, 1914, nr 5, s. 34.

64 [H. Szuman], Jak palenie szkodzi zdrowiu, NPrz, 1917, nr 10 (Kościuszkowski), s. 78-79.

65 [H. Szuman], Oddychajcie nosem!, NPrz, 1917, nr 1, s. 6.

${ }^{66}$ Ks. red. [H. Szuman], Jak siedzieć przy czytaniu i pisaniu?, NPrz, 1917, nr 8, s. 60.

${ }^{67}$ Wujek Zbigniew [W. Brzeska], Jak pisać?, NPrz, 1917, nr 6, s. 46; taż, Dzielenie wyrazów, tamże; taż, Wielką litera, tamże, 1917, nr 8, s. 63.

68 Jan Suchowiak (1861-1928), nauczyciel, organizator szkolnictwa w Wielkopolsce, działacz oświatowy. Inicjator powołania poradni szkolnej dla rodziców. Działał w zarządzie Towarzystwa Kolonii Wakacyjnych i Stacji Sanitarnej „Stella” oraz w Towarzystwie Pomocy Naukowej im. Karola Marcinkowskiego dla Młodzieży Wielkiego Księstwa Poznańskiego. Był inicjatorem i prezesem Powszechnego Towarzystwa Pedagogicznego im. Ewarysta Estkowskiego oraz wspólinicjatorem Towarzystwa Opieki Kulturalnej nad Polakami Zamieszkałymi Zagranicą im. Adama Mickiewicza. Ponadto był wizytatorem szkół powszechnych z ramienia Kuratorium Poznańskiego Okręgu Szkolnego. S. T. Sroka, Suchowiak Jan, [w:] Polski Słownik Biograficzny, t. 45, Warszawa-Kraków 2007-2008, s. 332-333.

69 H. Szuman, Każde dziecko polskie powinno umieć pisać po polsku, NPrz, 1915, nr 11, s. 87.

70 Wujek Zbigniew [W. Brzeska], Szkatułka czarodziejska, NPrz,1916, nr 4, s. 33-34.

${ }^{71}$ Ks. red. [H. Szuman], O ratowaniu tonących, NPrz, 1913, nr 2, s. 14; tenże, Jak ratować dziecko, które się załamało na lodzie?, tamże, 1917, nr 3, s. 21; tenże, Jak ratować siebie lub innych, gdy się odzież zapali?, tamże, 1918, nr 8, s. 51. 
w nim wskazówki, co należy po kolei robić, aby praca ta przynieść mogła wymierne korzyści i zadowolenie, a na koniec, gdy już w ogródku pojawią się pierwsze rośliny, a zwłaszcza kwiaty, radził przystrajać nimi przydrożne figurki i ołtarze na święto Bożego Ciała: „To też Jemu ofiarujcie pierwsze kwiatki z ogródeczka... l już - obraz święty stroi i figurę, ma dzieweczka [...]. - I podobnie ty postąpisz, drogi chłopcze - ogrodniku - przeczytawszy te wskazówki wszystkie w „Naszym Przewodniku"72.

Poprzez teksty zamieszczane na łamach pisemka starano się również uczyć najmłodszych dobrego wychowania i szacunku wobec ludzi starszych. Przykładowo w artykule Jak grzeczne dziecko pozdrawia? ks. Szuman zalecał, aby starszych i osoby duchowne pozdrawiać słowami „Niech będzie pochwalony Jezus Chrystus”, a pracujących „Szczęść Boże”. Oprócz pozdrawiania zalecał chłopcom na widok osób starszych zdejmować nakrycie głowy, a dziewczętom dygać. Wszystkim zaś dzieciom na znak szacunku wobec starszych nakazywał nisko się kłaniać, wstawać, gdy ktoś starszy wchodzi do pomieszczenia, puszczać przodem, ustępować miejsca. Zalecał ponadto całować osoby duchowne, a zwłaszcza księży w ręce, gdyż: „[...] ręce księdza są święcone i piastują Pana Jezusa przy mszy św.[iętej]"73.

Pewną wartość posiadają także artykuły pisane „ku przestrodze”. Zaliczyć do nich można teksty przestrzegające dzieci, by podczas zimowych dni nie wchodziły na zamarznięte zbiorniki wodne, gdyż grozić to może utonięciem ${ }^{74}$. W innym zaś tekście przestrzegano przed „uwieszaniem się" u chłopskich wozów, furmanek czy automobili, gdyż tego typu nierozsądne, a zarazem brawurowe zachowanie może stać się przyczyną trwałego kalectwa, a nawet śmierci ${ }^{75}$. U schyłku pierwszej wojny na łamach „Naszego Przewodnika” ukazał się natomiast artykuł przestrzegający najmłodszych, aby nie bawiły się bronią ani nabojami ${ }^{76}$.

Niezwykle interesujący jest tekst zawierający dziesięć przestróg dla dzieci odpoczywających podczas wakacji, gdyż wówczas mają one więcej wolnego czasu, którego nie potrafią należycie wykorzystać, a zamiast tego: „uwieszają się" jadących pojazdów, zaglądają do studni, kąpią się bez nadzoru osób dorosłych, podczas burzy schronienia szukają pod drzewami, poprzez nieznajomość leśnych grzybów zrywają trujące, jedzą niedojrzałe owoce, piją brudną wodę, zamiast mleka spożywają napoje alkoholowe, „bawią się ogniem” i bronią, dręczą zwierzęta. Ksiądz redaktor prosił usilnie, aby przestrogi te dzieci przepisały i powiesiły na drzwiach domostw ${ }^{77}$.

W nurcie abstynenckim utrzymane są artykuły-przestrogi dotyczące: zaczepiania osób pijanych, spożywania trunków alkoholowych i palenia papierosów ${ }^{78}$.

${ }^{72}$ Ks. [H.] Szuman, Ogródki zakładać!, NPrz, 1914, nr 5, s. 38.

${ }_{73}$ Red. [H. Szuman], Jak grzeczne dziecko pozdrawia?, NPrz, 1916, nr 10, s. 82-83.

74 [H. Szuman], Na świeży cienki lód nie wchodźcie dzieci !, NPrz, 1913, nr 2, s. 14.

75 [H. Szuman], Dzieci, nie uwieszajcie się nigdy u wozów !, NPrz, 1913, nr 6, s. 46.

76 [H. Szuman], Dzieci, nie podnoście naboi, nie bawcie się bronią!, NPrz, 1918, nr 2, s. 15.

77 Ks. red. [H. Szuman], Dziesięć przestróg na wakacje, NPrz, 1916, nr 7 (wakacyjny), s. 60.

78 [H. Szuman], Nie zaczepiajcie pijanych!, NPrz, 1913, nr 10, s. 75; tenże, Piotr, pijak - Jan, abstynent, tamże, 1916, nr 4, s. 32; tenże, Do czego wódka doprowadziła królewicza Ludwika, tamże, nr 5, s. 40-41; tenże, Kara za palenie papierosów, tamże, 1917, nr 12 (gwiazdkowy), s. 95. 
W jednym z tego typu tekstów, noszącym znamienny tytuł Spamiętajcie sobie, ks. Szuman podaje do czego doprowadzić może dzieci picie trunków ${ }^{79}$ oraz jakie korzyści przynosi wstrzemięźliwość ${ }^{80}$. Prosił, aby dzieci odwodziły rodziców, a zwłaszcza ojców od spożywania wódkii ${ }^{81}$ Zachęcał też dzieci z Wielkopolski, Pomorza oraz Królestwa Polskiego do wstępowania w szeregi członków abstynenckich związków (kółek) zrzeszających najmłodszych, czyli Bractw Dzieciątka Jezus, które w Galicji znane były jako Związki Anioła Stróża. Dziecięce związki abstynenckie istniały również wśród dzieci polskich na wychodźstwie w Nadrenii i Westfalii. Celem związków było: propagowanie przez dzieci wstrzemięźliwości od alkoholu przynajmniej w czasie przynależności do związku, a najlepiej do 16. roku życia; uczęszczanie na związkowe zebrania; odmawianie minimum raz dziennie modlitwy związkowej bądź modlitwy Zdrowaś Maryjo. W szeregi członków mogły wstępować dzieci, które ukończyły 6-7 lat i złożyły stosowne przyrzeczenie. Ksiądz Szuman oszacował, że w połowie 1914 r. do Bractw Dzieciątka Jezus i Związków Anioła Stróża mogło należeć ok. 12000 młodych abstynentów ${ }^{82}$.

Ważną funkcję wychowania w trzeźwości stanowiły też inicjowane przez redakcję „Naszego Przewodnika” tzw. Dni wstrzemięźliwości. Pierwsza tego typu akcja, posiadająca wymiar edukacyjny, społeczny, moralny i ekonomiczny, odbyła się w roku $1916^{83}$.

W 1919 r. miesięcznik zamieścił cały cykl artykułów, a właściwie pogadanek poświęconych walce $z$ alkoholizmem, ale w ujęciu biblijnym. W cyklu Pogadanki biblijne o alkoholu ukazały się łącznie trzy artykuły, z których pierwszy dotyczył patriarchy Noego, drugi króla Babilonu Baltazara, a trzeci proroka Daniela. Autorem tych pogadanek był bliżej nieznany ks. Bannwolf ${ }^{84}$.

Wychowanie do trzeźwości oraz w trzeźwości stanowiło dla wydawcy i redaktora „Naszego Przewodnika” fundamentalny cel "ogólnego wychowania młodego pokolenia" żyjącego w trudnych czasach najpierw zaborów, potem wojennej pożogi i wreszcie pierwszych lat budowania własnej państwowości. Jego wypowiedzi zamieszczane na łamach pisemka o wychowaniu w trzeźwości oraz do trzeźwości

79 „Dzieci pijące alkohol, 1. piją truciznę, 2. rosną cherlaczo, 3. są wątłe i blade, 4. źle sypiają i są nerwowe, 5. zarażają się łatwo i chorują dużo, 6. żyją krótko zazwyczaj, 7. są tępe i głupie, 8. są nieuważne i leniwe, 9. są krnąbrne i zuchwałe, 10. są psotne i okrutne, 11. mają dużo pokus brzydkich, 12. opuszczają pacierz i kościół". [H. Szuman], Spamiętajcie sobie, NPrz, 1917, nr 1, s. 2.

80 „Dzieci abstynenckie, 1. Pijąc świeżą wodę, mleko i maślankę, piją zdrowie, 2. wyrastają jak dęby, 3. są silne, tęgie i rumiane, 4. sypiają jak bobry, a nerwy mają jak postronki, 5. są zdrowe i wytrzymałe, 6. żyją zwykle długo, 7. są pojętne i zdolne, 8. są uważne i pilne, 9. są posłuszne i uprzejme, 10. są usłużne i litościwe, 11. umieją siebie przezwyciężać, 12. chodzą chętnie do kościoła i modlą się nabożnie". Tamże.

81 W. Theiss, Troska i nadzieja..., s. 113.

82 [H. Szuman], Abstynenckie związki dziatwy, NPrz, 1914, nr 8, s. 60-63.

83 W. Theiss, Troska i nadzieja..., s. 114.

84 Ks. Bannwolf, Pogadanki biblijne o alkoholu. Noe, NPrz, 1919, nr 3, s. 18-19; tenże, Pogadanki biblijne o alkoholu. Noe. (Dokończenie), tamże, nr 4, s. 26-27; tenże, Pogadanki biblijne o alkoholu. Król Baltazar, tamże, nr 5, s. 33-34; tenże, Pogadanki biblijne o alkoholu. Król Baltazar. (Dokończenie), tamże, nr 6 i 7, s. 38-40; tenże, Pogadanki biblijne o alkoholu. Daniel, tamże, nr 8 i 9, s. 49-51; tenże, Pogadanki biblijne o alkoholu. Daniel. (Ciąg Dalszy), tamże, nr 10-12, s. 56-58. 
należą niewątpliwie do nurtu społeczno-wychowawczego wytyczonego przez ks. Bronisława Markiewicza ${ }^{85}$ w redagowanym przez niego miesięczniku „Powściągliwość i Praca". Zarówno ks. Markiewicz, jak i ks. Szuman z podobnym sobie zaangażowaniem podjęli walkę z nałogami, a zwłaszcza z paleniem tytoniu i piciem napojów alkoholowych przez dzieci i młodzież ${ }^{86}$.

Poprzez teksty zamieszczane na łamach „Naszego Przewodnika” starano się wdrażać u dzieci zasady oszczędności. Wanda Brzeska proponowała na przykład, aby dzieci bożonarodzeniowe choinki przystrajały w samodzielnie wykonane ozdoby, a nie prosiły o ich zakup rodziców, gdyż czasy wojenne nie sprzyjały rozrzutności. Poprzez stosowne teksty starano się również uczyć najmłodszych poszanowania pokarmów, dzielenia się nimi z głodnymi kolegami i koleżankami, oduczać grymaszenia ${ }^{87}$.

Zarówno osoby starsze, jak i dzieci prosił ks. Szuman o opiekę nad sierotami i bezdomnymi. We wrześniu 1915 r. na łamach miesięcznika znalazł się tekst, w którym redakcja apelowała o przygarnięcie pięciorga osieroconego rodzeństwa z Prus Zachodnich. Zastrzegano jednak, że po sieroty zgłaszać się mogą jedynie rodziny uczciwe i bogobojne. Odzew okazał się natychmiastowy, gdyż już w następnym numerze zamieszczona została informacja, że osierocone dzieci znalazły domy w jednej wsi. Jednocześnie ks. Szuman pisał, że nie czuje się odpowiedzialny za los owych sierot w nowych rodzinach, lecz poprzez swoje prośby pragnął jedynie zapewnić im schronienie, ufając w szczerość intencji tych, którzy je przygarnęli88.

Poprzez artykuł Robótki dla małych rączek na Bazary Gwiazdkowe ks. Szuman uczył najmłodszych ofiarności wobec najbardziej potrzebujących pomocy, głodnych dzieci z Królestwa Polskiego, których liczbę oszacowano na przeszło 70 000. Bazary Gwiazdkowe organizowane były w 1916 r. w licznych pomorskich miastach, takich jak: Toruń, Gdańsk Chełmno, Chełmża, Brodnica, Grudziądz, Sztum, Nowe, Wąbrzeźno, Lubawa, Świecie, Pelplin. Bazary Gwiazdkowe były składami gromadzącymi różne przedmioty podarowane przez ludzi dobrej woli, a przydatne na świąteczne upominki. Dochód ze sprzedaży tych przedmiotów przeznaczony został na potrzeby ubogich dzieci z Królestwa Polskiego, ofiar wojennych umieszczonych w ochronkach. Zachęcając pomorskie dzieci do wzięcia udziału w tym pożytecznym przedsięwzięciu, wydawca i redaktor prosił, aby przekazywały głównie wyroby wykonane pracą własnych rąk, a więc: zabawki, ozdobne pudełeczka, krzyże, ramki do obrazków i fotografii, wykonane z wełny robótki ręczne, a następnie dostarczyły je do najbliższego tego typu składu lub nadsyłały

85 Bronisław Markiewicz (1842-1912), kapłan katolicki, salezjanin, działacz społeczny, wychowawca opuszczonej i zaniedbanej młodzieży (zwłaszcza męskiej). Założyciel i dyrektor w Miejscu Piastowym (diecezja przemyska) Instytutu „Powściągliwość i Praca” oraz miesięcznika o tej samej nazwie. Założyciel zgromadzeń zakonnych św. Michała Archanioła. Szerzej zob. m.in.: W. Michułka, Błogosławiony ks. Bronisław Markiewicz (1842-1912). Wychowawca opuszczonej młodzieży i założyciel zgromadzeń zakonnych św. Michała Archanioła, Marki 2005.

86 W. Theiss, Ks. Henryk Szuman..., s. 78.

87 Wujek Zbigniew [W. Brzeska], Na choinkę, NPrz, 1914, nr 12, s. 94; Z. Weiner, Nie marnować i nie niszczyć pokarmów!, tamże, 1918, nr 3, s. 18.

${ }^{88}$ H. Szuman, Kto przyjmie w dom sierotkę?, NPrz, 1915, nr 9, s. 70; tenże, Dobrzy ludzie zgłosili się po sieroty, tamże, nr 10, s. 75. 
do jego siostry - Wandy, która zobowiązała się przekazać je Bazarowi Gwiazdkowemu w Toruniu ${ }^{89}$.

„Nasz Przewodnik” jako miesięcznik skierowany w głównej mierze do najmłodszych odbiorców propagował również wszelkie formy aktywności dzieci i młodzieży. Na łamach pisemka zachęcano do uprawiania sportu i spędzania wolnego czasu podczas zabaw na świeżym powietrzu. Autorzy artykułów, na czele z ks. Szumanem, w swych tekstach wyjaśniali reguły licznych zabaw i gier, takich chociażby jak: zabawa w kolej, w dzwon spiżowy, chowanego, gra w kulawego lisa, gra w kwiaty, czarodzieja, łapki, przeciąganego i wiele innych. Ponadto propagowane były rozrywki umysłowe, liczne łamigłówki (w tym obrazkowe), rebusy i zagadki. Uczono także najmłodszych, jak samodzielnie wykonać mogą zabawki czy mniej skomplikowane przedmioty codziennego użytku z drewna, słomy, papieru, wełny, skrawków tkanin.

W miesięczniku pojawiały się również teksty pieśni i licznych piosenek dziecięcych, niejednokrotnie wraz z załączonym dodatkiem nutowym. Wśród utworów muzycznych na szczególną uwagę zasługuje śpiewany na nutę pieśni maryjnej Chwalcie łąki umajone - Hymn dzieci abstynenckich oraz specjalnie ułożony przez ks. Antoniego Kowalkowskiego ${ }^{90}$ - Marsz dzieci abstynenckich. Redaktor i wydawca namawiał dzieci, aby wszelkie pieśni i piosenki z „Naszego Przewodnika” starannie przepisywały do osobnych zeszytów i w ten sposób tworzyły własne śpiewniczki ${ }^{91}$.

Wiele treści na łamach „Naszego Przewodnika” wypełniały utwory liryczne. Były to najczęściej krótkie rymowane wierszyki pisane i publikowane na specjalne okazje, takie jak: święta, wakacje, pory roku, liryki opiewające piękno ojczystej przyrody, ziemi rodzinnej, osób godnych naśladowania. Zamieszczano również legendy, historyczne i religijne powiastki oraz opowiadania pisane najczęściej przez ks. Antoniego Szumana i Wandę Brzeską. W każdym numerze znajdowały się ponadto skierowane do młodych czytelników: złote myśli, aforyzmy, sentencje, maksymy, cytaty sławnych ludzi, przysłowia ludowe.

\section{„Nasz Przewodnik” w czasach ks. Józefa Janiszewskiego}

W styczniu 1920 r. nowym redaktorem pisemka został ks. Józef Janiszewski ${ }^{92}$, który poinformował o tym fakcie czytelników i prenumeratorów, pisząc: „[...] założyciel «Naszego Przewodnika» ks. Henryk Szuman, który tak świetnie

89 Ks. red. [H. Szuman], Robótki dla małych rączek na Bazary Gwiazdkowe, NPrz, 1916, nr 11, s. 86-87; tenże, Idźcie, spieszcie do bazaru, „Gazeta Toruńska” 1916, nr 292, s. [1].

90 Antoni Kowalkowski (1866-1932), kapłan katolicki, autor pieśni kościelnych, działacz społeczny i oświatowy. Ksiądz Kowalkowski był członkiem Towarzystwa Naukowego w Toruniu, organizatorem oddziału Towarzystwa Ludowego, zaangażowany był ponadto w prace Katolickiego Stowarzyszenia Młodzieży oraz w działalność Ligi Katolickiej. W swej pracy kapłańskiej i duszpasterskiej szczególnie dużo uwagi poświęcił dzieciom i ich wychowaniu. K. Kowalkowski, Ks. Antoni Kowalkowski, „Moje Miasto" 2010, nr 16, s. [1], http://www.mojemiasto.slupsk.pl/index.php?id=4267 [dostęp: 22.11.2012].

91 [H. Szuman], Mój śpiewniczek, NPrz, 1914, nr 4, s. 27.

92 Józef Janiszewski (1880-1940), kapłan katolicki, pastoralista, działacz abstynencki. Urodził się w Poznaniu, lecz w czasach gimnazjalnych z powodu przynależności do tajnych kółek młodzieży 
go redagował [...] z powodu nadmiaru zajęć innych złożył redakcję «Naszego Przewodnika» w ręce moje. Wiem, że wiadomość ta wyciśnie [...] łzy żalu za ukochanym [...] księdzem redaktorem, który tak pięknie i tak serdecznie umiał do serduszek [...] przez te siedem lat przemawiać, i zaszczepiać w nie dobre rady i nauki [...]. Lecz osłodą i pociechą [...] niech będzie myśl, że dawny [...] ksiądz redaktor i dziś o was [dzieci] pamięta, bo zajęty jest obecnie założeniem i urządzeniem letniska dla dzieci w Gdyni [...] i Towarzystwem Pomorskim Opieki nad Dziećmi. [...] małą część tej miłości i tego przywiązania chciejcie przelać na nowego [...] redaktora, który [...] z obawą w sercu podjął się tego zaszczytnego lecz i trudnego i odpowiedzialnego obowiązku. [...] Prosi [...] też gorąco nowy redaktor, byście «Naszego Przewodnika» pokazywały i innym dzieciom, które go nie znają i zachęcały je do zaabonowania go sobie"93.

W czasach, gdy redaktorem „Naszego Przewodnika” był ks. Janiszewski, to redakcja pisma mieściła się w Poznaniu, podobnie jak dział ekspedycji, który znajdował się przy Składnicy Abstynenckiej. Drukiem miesięcznika zajmowała się Drukarnia Poznańska Towarzystwa Akcyjnego, mieszcząca się przy ulicy 27 Grudnia 5. Roczna prenumerata pisemka z uwagi na zwiększone koszty papieru i druku wynosiła wówczas 5 marek polskich ${ }^{94}$.

Pomimo szczerych intencji i chęci nowego redaktora „Nasz Przewodnik” nie cieszył się już taką popularnością, jak w czasach, kiedy wydawał i redagował go ks. Szuman. Ukazały się bowiem wówczas (1920 r.) zaledwie cztery skumulowane numery, a ich łączna objętość wyniosła zaledwie 48 stron.

\section{„Mały Światek”}

Ksiądz Henryk Szuman nie zaprzestał jednak całkowicie pracy redakcyjnej, czego przykładem jest redagowany przez niego w latach 1925-1927 „Mały Światek” - ilustrowany miesięcznik przeznaczony dla starszej „dziatwy”. „Mały Światek" powstał w wyniku fuzji trzech pism, wydawanych z myślą o młodych odbiorcach, a mianowicie ukazującego się we Lwowie od 1887 r. „Małego Światka” ${ }^{\text {, }}$ wychodzącej w latach 1918-1921 poznańskiej „Warty” oraz zlikwidowanego

polskiej zmuszony był opuścić Wielkopolskę. Seminarium Duchowne ukończył w 1906 r. we Lwowie. Po święceniach pracował jako wikary w Hliboce (niedaleko Czerniowiec), gdzie włączył się w działalność abstynencką. Po odzyskaniu przez Polskę niepodległości powrócił w rodzinne strony, gdzie w Poznaniu objął stanowisko sekretarza generalnego „Wyzwolenia” i Związku Księży Abstynentów. W 1921 r. zrezygnował z tej funkcji i przeszedł do pracy duszpasterskiej. W 1934 r. odszedł na emeryturę. Ksiądz Janiszewski był autorem broszur, wierszy i piosenek poświęconych walce z pijaństwem i szerzeniu abstynencji oraz kazań i homilii niedzielnych i świątecznych publikowanych na łamach „Przewodnika Katolickiego” i „Nowej Biblioteki Kaznodziejskiej”. M. Banaszak, Janiszewski Józef, [w:] Słownik polskich teologów katolickich 1918-1981, t. 5, A-J, red. L. Grzebień, Warszawa 1983, s. $575-576$.

93 J. Janiszewski, Od nowej redakcji, NPrz, 1920, nr 85 i 86, s. 1-2.

94 Tamże, s. 2.

$95 \mathrm{Na}$ temat ukazującego się we Lwowie od $1887 \mathrm{r}$. ilustrowanego czasopisma dla dzieci i młodzieży pt. „Mały Światek” zob. szerzej: S. Grabowski, Na przyszły pożytek. Z dziejów polskiej prasy dla dzieci 1824-1939, Pultusk 2001, s. 88-99. 
w styczniu 1921 r. pomorsko-poznańskiego „Naszego Przewodnika”. Nowe pismo ukazywało się nakładem Zjednoczenia Stowarzyszeń Młodzieży Polskiej w Poznaniu, a drukowała je Spółka Akcyjna „Ostoja”. Redakcja miesięcznika mieściła się w Nawrze, gdzie wówczas ks. Szuman pracował jako proboszcz. Pierwszy numer „Małego Światka” ukazał się 15 stycznia 1925 r. i zawierał, podobnie jak pozostałe numery, szereg artykułów o treści historycznej i patriotycznej ${ }^{96}$.

O popularności, jaką cieszył się wśród odbiorców „Mały Światek”, świadczy duża liczba listów napływających na ręce księdza redaktora (ok. 1000), które wszystkie wnikliwie czytał, aby dowiedzieć się, jakie treści zamieszczane na łamach miesięcznika cieszą się największym zainteresowaniem i co zrobić, aby w przyszłości móc jeszcze bardziej ulepszyć i uatrakcyjnić pisemko ${ }^{97}$.

\section{Podsumowanie}

Redagowany i wydawany przez ks. Henryka Antoniego Szumana „Nasz Przewodnik" odznaczał się dobrym poziomem edytorskim oraz merytorycznym. Był miesięcznikiem popularnym i miał szeroki zasięg terytorialny. Niewątpliwie odegrał doniosłą rolę religijną, moralną, wychowawczą, patriotyczną, a nawet artystyczną. W okresie zaborów wychowywane w niemieckich i rosyjskich szkołach dzieci uczył polskości, poszanowania tradycji, kultury i wiary ojców. W okresie pierwszej wojny światowej i po odzyskaniu przez kraj niepodległości uczył życia w wolnej Polsce. Ponadto znakomicie ukazywał postać ks. Szumana, który wszystko, co czynił - czynił z myślą o najmłodszych. Dzieciach z ubogich rodzin, sierotach, zaniedbanych wychowawczo, które nie zaznały domowego ciepła, matczynej miłości, radości dorastania, a nagminnie spotykały się z pijaństwem i niejednokrotnie „przymierały głodem”. W licznych artykułach i opowiadaniach zamieszczanych na łamach „Naszego Przewodnika” zarówno ksiądz redaktor, jak i inni autorzy i korespondenci, uczyli dzieci miłości do Boga, ojczystego kraju i drugiego człowieka, tłumaczyli obrzędy roku liturgicznego, apelowali o pomoc dla sierot i biednych, ostrzegali przed paleniem papierosów i piciem alkoholu, gdyż nałogi te niszczyły zdrowie i siły, a alkohol ponadto prowadził do nieszczęść i nieporozumień w życiu rodzinnym, rujnował materialnie ${ }^{98}$.

W Kąciku liścików w kwietniu 1917 r. został zamieszczony tekst ks. Szumana, który najlepiej odzwierciedla rolę tego miesięcznika: „Kochane dzieci! Z licznych listów Waszych widzę, że szczerze kochacie pisemko swoje i korzystacie zeń bardzo. Wszak już samo pisanie starannych listów do redakcji przynosi Wam dużo pożytku, ćwiczy w poprawnym pisaniu, uczy myślenia, wypowiadania się, budzi zajęcie dla pisemka, zaznajamia z innymi dziećmi, zachęca do pracy nad sobą itd. - Dużo dzieci, zachęconych przykładem dzieci z innych stron, zabrało

96 H. Mross, Szuman Henryk..., s. 246-247; J. Sajewicz, Głos mają sieroty..., s. 57; K. Dąbrowski, Ksiądz prałat Henryk Antoni Szuman..., s. 50; A. Wałęga, Ksiądz Henryk Antoni Szuman..., s. 170.

97 K. Dąbrowski, Ksiądz prałat Henryk Antoni Szuman..., s. 50.

98 Tamże, s. 58-59; W. Theiss, Troska i nadzieja..., s. 109, 111. 
się nie tylko do pisania listów, ale nadto do uczenia młodszego rodzeństwa (w ten sposób same najwięcej korzystają), do uczenia się historii polskiej, do czytania książek [...], do przepisywania wierszy z pisemka, uczenia się tychże na pamięć, do ćwiczenia pieśni podanych i nowych gier, zrobienia robótek zaleconych, ofiarowania oszczędzonych groszy na głodne dzieci, do zupełnej wstrzemięźliwości od trunków i tytoniu, do sztuki przezwyciężania się w niejednym, wreszcie do pobożnej modlitwy i gorliwego uczęszczania do sakramentów świętych, dających siły do życia dobrego. Nie dziw więc, że kochacie swoją gazetkę, która tyle dobrego dzieciom czyni"99.

${ }_{99}$ H. Szuman, Kącik liścików, NPrz, 1917, nr 4, s. 31. 